\title{
India's gender equity journey: Access to resources
}

\author{
PRITISHRI PARHI AND MANASHI MOHANTY
}

Received: 25.11.2014; Accepted: 15.05.2015

See end of the paper for authors' affiliations PRITISHRI PARHI

College of Home Science, Orissa University of Agriculture and Technology, BHUBANESWAR (ODISHA) INDIA

Email : pritishri.parhi11@gmail.com
ABSTRACT : In India rural women play a significant and crucial role in agriculture development and allied fields including in the main crop production, livestock production, horticulture, post harvest operations, agro-social forestry and fishery etc. They act as farm producers, wage earners, and care takers of the family. With so much of contribution by women in on farm and off farm activities it is unfortunate that power, authority, decision-making and access to resources issues seem to rest exclusively with the males and eventually women acquired a role slowly, which lost its dignity, respect and values. Unequal access to resources limits women's capacity to ensure agricultural productivity, security life hoods and food security and is increasingly linked to poverty, migration, urbanization and increased risk of violence. Women's access to all financial services, including savings, insurance and remittance transfers and credit, is essential to allow them to benefit fully from economic opportunities.

KEY WORDS: Gender equity, Resources

— HOW TO CITE THIS PAPER : Parhi, Pritishri and Mohanty, Manashi (2015). India's gender equity journey: Access to resources. Asian J. Home Sci., 10 (1) : 232-234. 